\title{
PERANAN PEMERINTAH KOTA BATU DAN PEMERINTAH DESA PUNTEN DALAM PEMBERDAYAAN WISATA PETIK APEL
}

\author{
Roro Merry Chornelia Wulandary dan Abd. Rohman \\ Program Studi Ilmu Administrasi Negara, FISIP, Universitas Tribhuwana Tunggadewi \\ Jl. Telaga Warna Blok C, Tlogomas, Kec. Lowokwaru, Kota Malang. \\ Email: merry.chornelia@yahoo.com
}

\begin{abstract}
The Role of Tourism Office Batu City and Punten Village Government in tourism empowerment is very influential to the progress of Apple Picking Tour which is located in Punten Village, Batu City. This research aims to describe the role of Culture and Tourism Office also The Village Government in manifestation and implementation the mechanism of the tourism maximally. The research uses qualitative method with data collection techniques through interview, observation, and documentation. Data analysis is done in several stages, including data eduction, data presentation and taking the conclusion. The results show that the role of Culture and Tourism Office and Village Government in empowering An Apple Picking Tour was carried through collaboration and give encouragement to the society, to establish the Group of Tourism Consciousness/Kelompok Sadar Wisata, and Joint Farmer Group/Gabungan Kelompok Tani (Pokdarwis \& Gapoktan), having coordination among the Culture and Tourism Office, Village Government and community, and also to have a Development Plan Deliberation (Musrenbang) in a village level.
\end{abstract}

Keywords: Local Government, Empowerment, Apple Picking Tour.

Abstrak. Peranan Dinas Pariwisata Kota Batu dan Pemerintah Desa Punten dalam pemberdayaan wisata sangat berpengaruh pada perkembangan wisata petik apel yang ada di Desa Punten, Kota Batu. Penelitian ini bertujuan untuk menggambarkan peranan Dinas Pariwisata Kota Batu serta Pemerintah Desa Punten dalam memajukan pariwisata secara maksimal, terutama wisata petik apel yang ada di Desa Punten. Penelitian ini menggunakan metode kualitatif dengan tehnik pengumpulan data melalui wawancara, observasi dan dokumentasi. Analisis data dilakukan dengan beberapa tahap, diantaranya reduksi data, penyajian data dan penarikan kesimpulan. Hasil penelitian menunjukan bahwa peranan Dinas Pariwisata Kota Batu serta Pemerintah Desa Punten dalam mengembangkan wisata petik apel dilakukan melalui kerjasama dan memberikan dorongan kepada masyarakat dengan membentuk Kelompok Sadar Wisata dan Gabungan Kelompok Tani (Pokdarwis \& Gapoktan), melakukan koordinasi antara Dinas Pariwisata, Pemerintah Desa dan masyarakat, serta mendorong adanya musrembang di tingkat desa.

Kata Kunci: Pemerintah Daerah, Pemberdayaan, Wisata Petik Apel.

\section{PENDAHULUAN}

Otonomi daerah menurut Undang-Undang Nomor 23 Tahun 2014 tentang Pemerintah Daerah adalah hak, wewenang, dan kewajiban daerah otonom untuk mengatur dan mengurus sendiri Urusan Pemerintahan dan kepentingan masyarakat setempat dalam sistem Negara Kesatuan Republik Indonesia. Untuk itu disini daerah diharapkan mempunyai kemampuan untuk menyediakan dan menggali potensi yang ada, termaksud didalamnya dengan membangun potensi pariwisata.

Tujuan dari otonomi daerah adalah yang pertama meningkatkan Pelayanan Umum. Dengan adanya otonomi daerah diharapkan ada peningkatan pelayanan umum secara 
maksimal dari lembaga pemerintah di masing-masing daerah. Dengan pelayanan yang maksimal tersebut diharapkan masyarakat dapat merasakan secara langsung manfaat dari otonomi daerah. Kedua, meningkatkan kesejahteraan Masyarakat, Setelah pelayanan yang maksimal dan memadai, diharapkan kesejahteraan masyarakat pada suatu daerah otonom bisa lebih baik dan meningkat. Tingkat kesejahteraan masyarakat tersebut menunjukkan bagaimana daerah otonom bisa menggunakan hak dan wewenangnya secara tepat, bijak dan sesuai dengan yang diharapkan. Ketiga, meningkatkan daya saing daerah, dengan menerapkan otonomi daerah diharapkan dapat meningkatkan daya saing daerah dan harus memperhatikan bentuk keanekaragaman suatu daerah.

Beberapa daerah yang mampu menjalankan otonomi mampu mandiri dalam mengelola kebutuhan daerahnya dengan memberdayakan potensi yang ada, salah satu potensi daerah yang bisa diberdayakan adalah sektor pariwisata. Sektor pariwisata merupakan sektor yang menarik dalam upaya meningkatkan devisa baik kelas Nasional maupun daerah setelah sektor migas dan sektor lainnya. Peran yang diberikan adalah semakin banyak wisatawan yang datang, maka secara otomatis semakin besar pula devisa yang diperoleh karena ada kegiatan ekonomi didalamnya.

Pengembangan pariwisata dapat diartikan sebagai suatu proses pengembangan di daerah tujuan wisata. Bentuk pengembangan pariwisata dapat berupa pengembangan atraksi atau obyek wisata, pengadaan dan rehabilitasi sarana maupun prasarana pariwisata. Pengembangan pariwisata di suatu daerah tujuan wisata harus didasarkan pada perencanaan, pengembangan dan arah pengelolaan yang jelas agar semua potensi yang dimiliki suatu daerah tujuan wisata dapat diberdayakan secara optimal untuk kesejahteraan masyarakat. Tolak ukur dari perkembangan pariwisata bisa dilihat dari jumlah pengunjung dari tahun ketahun semakin meningkat maka dapat diartikan bahwa pariwisata tersebut berkembang dengan baik. Sebuah obyek wisata akan banyak dikunjungi oleh wisatawan apabila didukung oleh fasilitas penunjang, misalnya pembangunan fasilitas yang dibutuhkan oleh pengunjung. Penyediaan fasilitas yang mendukung dapat menarik para wisatawan untuk berkunjung kesuatu obyek wisata.

Dalam proses pengembangan pariwisata harus mampu mengubah persepsi, sikap dan motivasi stakeholder (pemangku kepentingan) untuk berbuat sesuai dengan arah dan kriteria baru untuk pengembangan dan pendayagunaan berbagai potensi kepariwisataan yang ada, yaitu memerlukan pengetahuan khusus untuk mencapai harga penjualan yang tinggi untuk produk-produk pariwisata yang ada sehingga nilai jual obyek tersebut memiliki nilai jual pada wisatawan.

Di Indonesia sendiri terdapat banyak daerah yang memiliki kekayaan alam dan budaya yang potensial untuk dibangun dan dikembangkan dalam kerangka kepariwisataan, serta memiliki kemampuan untuk menjadi salah satu destinasi pariwisata kelas dunia. Lahan yang subur, lautan yang luas, khasanah budaya yang beragam dan tak terkira jumlahnya, sumber daya alam yang melimpah, serta keindahan fenomena alam merupakan modal besar yang secara alamiah telah terdapat melimpah di seluruh pelosok nusantara. Untuk itu tentunya ada kesempatan bagi daerah untuk menggarap dan membangun potensipotensi pariwisata tersebut dengan optimum sebagai sektor yang berpeluang menjadi sektor unggulan.

Dalam pariwisata akan ada pengaruh bagi masyarakat lokal daerah yang menjadi tempat wisata tersebut, pengaruh tersebut meliputi ekonomi dan sosial,dari adanya kontak dengan wisatawan. Disisi ekonomi kehidupan masyarakat lokal di daerah tempat wisata 
tersebut akan meningkat karena tujuan dari membuka sektor wisata adalah untuk mensejahterakan masyarakat salah satunya masyarakat bisa melakukannya dengan menjual produk daerahnya kepada wisatawan yang datang ketempat wisata tersebut. Disisi sosial kehidupan masyarakat akan berubah dari yang mungkin dulunya masyarakat bermata pencarian dengan bertani setelah adanya sektor pariwisata masyarakat lebih banyak masyarakat membuka usaha, baik usaha besar maupun usaha kecil terlebih masyarakat dengan bekerjasama dengan pemerintah untuk menyediakan fasilitas yang lengkap dalam mendukung tempat wisata tersebut agar memperbanyak wisatawan yang datang untuk berkunjung di tempat wisata tersebut dan mata pencarian bertani mulai akan berkurang.

Dalam mengembangkan atau menciptakan tempat wisata Pemerintah mempunyai peran penting karena sektor pariwisata tidak dapat berkembang secara maksimal jika tidak ada campur tangan dari Pemerintah terutama dalam penyediaan fasilitas akses jalan, mencari wisatawan dan mempromosikan tempat wisata tersebut. Adanya Dinas Pariwisata dan Kebudayaan dapat membantu daerah wisata dalam mengembangkan potensi wisata di daerah tersebut karena Dinas Pariwisata dan Kebudayaan merupakan Instansi dari Pemerintah Daerah yang bertugas langsung untuk melaksanakan urusan pemerintah di bidang kebudayaan dan pariwisata berdasarkan asas otonomi dan tugas pembantu. Dengan adanya Bidang Pariwisata perencanaan strategis pada Dinas Pariwisata dan Kebudayaan yang lebih teratur, dapat merumuskan kebijakan teknis di bidang Kebudayaan dan Pariwisata, adanya penyelenggaraan pemerintah dan pelayanan umum di bidang Kebudayaan dan Pariwisata, adanya pembinaan dan pelaksanaan tugas di bidang Kebudayaan dan Pariwisata, adanya pelaksanaan dan pengawasan serta evaluasi dan pelaporan penyelenggara di bidang Kebudayaan dan Pariwisata, adanya pelaksanaan standar pelayanan minimal yang wajib dilaksanakan di bidang Kebudayaan dan Pariwisata untuk meningkatkan kualitas tempat wisata tersebut, tempat membuat perizinan dan pelaksanaan pelayanan di bidang seni budaya dan pariwisata, memberi pembinaan kepada masyarakat tentang kebudayaan dan pariwisata dan meningkatkan pengembangan apresiasi seni budaya, serta pembinaan pengembangan obyek wisata pentas seni budaya rekreasi dan aneka hiburan.

Potensi pemerintahan tingkat pedesaan yang dapat di reposisi menjadi desa wisata, untuk menjadi suatu daerah tujuan wisata yang menarik untuk dikunjungi, daerah tersebut harus memenuhi persyaratan utama antara lain: Pertama, sesuatu yang menarik untuk dilihat yaitu di tempat tersebut harus ada obyek wisata dan atraksi wisata, misalnya daerah tersebut adalah daerah yang memiliki pegunungan, pantai, air terjun, serta kebudayaan masyarakat yang unik dan menarik sehingga dapat menarik wisatawan untuk berkunjung ke daerah tersebut. Kedua, terdapat sesuatu yang bisa dilakukan pengunjung yaitu di tempat tersebut selain banyak yang dapat disaksikan dan dilihat, harus pula disediakan fasilitas rekreasi atau amusements, misalnya ditempat atau obyek wisata tersebut menyediakan fasilitas seperti hotel atau penginapan sehingga wisatawan dapat beristirahat, sumber informasi sehingga wisatawan dapat dengan mudah mencari informasi tentang tempat wisata yang akan dikunjungi, dan parkiran sehingga wisatawan dapat menyimpan kendaraannya. Ketiga sesuatu yang dapat dibeli yaitu di tempat tersebut ada fasilitas untuk berbelanja. Dari ketiga syarat tersebut dapat menjadi nilai jual terhadap pasar untuk pengembangan pariwisata, sehingga dapat menahan wisatawan untuk tinggal berhari-hari dan diharapkan dapat menarik wisatawan untuk berkunjung berkali-kali. 
Desa Punten merupakan desa wisata yang cukup terkenal di Kota Batu. Salah satu tempat wisata yang sering dikunjungi oleh wisatawan di Desa Punten adalah wisata petik apel, dibandingkan dengan wisata-wisata yang lain. Wisata petik apel yang ada di Desa Punten lebih terkenal dari pada wisata-wisata yang lainnya karena wisata ini selain dapat pengalaman baru disana juga bisa belajar mengenali berbagai jenis apel yang ada di Kota Batu. Suksesnya wisata petik apel ini tidak lepas dari peranan Pemerintah Daerah untuk mengembangkannya, dalam hal ini Dinas Pariwisata dan Pemerintah Desa Punten yang mempunyai peranan penting. Untuk itu bagaimana peranan Dinas Pariwisata dan Pemerintah Desa Punten untuk mengembangkan wisata petik apel yang ada di Desa Punten menjadi perhatitan dalam penelitian ini.

\section{METODE PENELITIAN}

Jenis penelitian ini menggunakan metode penelitian kualitatif. Menurut Moleong (2012) penelitian kualitatif adalah penelitian yang bermaksud untuk memahami fenomena tentang apa yang dialami oleh subjek penelitian misalnya prilaku, persepsi, motivasi, tindakan, dll., secara holistik, dan dengan cara deskripsi dalam bentuk kata-kata dan bahasa, pada suatu konteks khusus yang alamiah dan dengan memanfaatkan berbagai metode ilmiah. Tehnik pengumpulan data menggunakan wawancara, observasi dan dokumentasi. Wawancara dalam penelitian ini dilakukan secara terstruktur, dan dengan tatap muka (face to face (Bungin, 2007). Informan dalam penelitian ini yaitu Dinas Pariwisata dan Kebudayaan Kota Batu, Pemerintah Desa Punten, Kelompok Sadar Wisata (Pokdarwis) dan Gabungan Kelompok Tani (Gapoktan). Analisis data yang digunakan adalah teori Miles dan Huberman yaitu data reduction, data display, dan conclusion drawing/verification (dalam Sugiyono, 2013).

\section{HASIL DAN PEMBAHASAN}

\section{A. Peranan Dinas Pariwisata dan Kebudayaan Serta Pemerintah Desa}

Peranan Dinas Pariwisata dan Pemerintah Desa Punten sangat mempengaruhi perkembangan desa punten dalam mewujudkan desa wisata petik apel karena tanpa peranan dari dinas pariwisata dan pemerintah desa wisata petik apel di desa punten tidak akan bisa diwujudkan. Desa punten menjadi desa wisata petik apel melalui kebijakan yang dibuat dalam Musrembang tingkat desa, setelah dibentuk desa punten sebagai desa wisata petik apel maka lahirlah strategi-strategi dalam mewujudkan wisata petik apel yaitu yang pertama pembentukan kelompok sadar wisata atau pokdarwis, pokdarwis adalah kelompok sadar wisata yang dibentuk oleh pemerintah desa dengan bimbingan dinas pariwisata, ranah strategi di pokdarwis adalah memberikan informasi tentang kepariwisataan, penguatan ikon punten sebagai wisata petik apel, pemberian informasi kesegala media tentang segala wisata petik apel begitu juga tentang pembukaan lahan untuk wisata petik apel. Hal ini diperkuat dengan peranan pemerintah daerah terhadap pengembangan pariwisata yaitu peranan Dinas Pariwisata dan Pemerintah Desa Punten dalam pemberdayaan petani apel. Dan dapat kita lihat dari empat indikator Menurut Pitana dan Gayatri (2005) ada empat peran penting untuk mengembangkan potensi pariwisata daerah, yakni Koordinator, Motivator, Fasilitator, dan Dinamisator.

\section{1) Koordinasi}

Dalam mengembangkan suatu obyek wisata tentu ada koordinasi antara suatu instansi pemerintah agar wisata tersebut dapat berkembang dengan baik. Pemerintah daerah 


\section{REFORMASI}

dapat menjadi koordinator dalam membuat kebijakan atau mengusulkan strategi-strategi bagi pembangunan di daerahnya. Dalam merencanakan suatu kebijakan baru perlu adanya musyawarah bersama sehingga dapat membuat suatu kesepakatan bersama antara dinas pariwisata, pemerintah desa, dan kelompok masyarakat lainnya agar dapat mengembangkan obyek wisata dengan baik.

Dinas Pariwisata dalam melakukan koordinasi dengan ikut berperan dalam memberi saran atas kebijakan-kebijakan dari hasil musyawarah dan mufakat yang dilakukan oleh pemerintah desa dan masyarakat desa punten, yang berkenaan dengan mengembangkan wisata petik apel. Pemerintah desa dan masyarakat desa punten mengadakan musyawarah rencana pembangunan atau musrembang, hasil dari musrembang tingkat desa yang dilakukan oleh pemerintah desa punten dengan masyarakat yaitu masyarakat mengusulkan bahwa perlu adanya pengembangan pembangunan sektor wisata petik apel. Dari usulan tersebut pemerintah desa mengkoordinasikannya kepada dinas pariwisata setelah itu Dinas Pariwisata dan Pemerintah membuat perjanjian khusus atau MOU dimana didalamnya Rencana struktur pusat pelayanan di Kota Batu Desa Puten ditetapkan menjadi Bagian Wilayah Kota (BWK) III dengan pusat pelayanan di Desa Punten, BWK III ini meliputi Desa Punten, Desa Sidomulyo, Desa Bulukerto, Desa Gunungsari, Desa Sumberejo.

Rencana struktur kegiatan fungsional yang akan dikembangkan di Kota Batu berdasarkan Bagian Wilayah Kota Kegiatan primer adalah kegiatan fasilitas yang mempunyai jangkauan pelayanan kota dan regional dengan didukung potensi, daya dukung lahan sosial budaya dan sistem jaringan jalan yang ada maupun yang akan dikembangkan sedangkan Kegiatan Sekunder adalah kegiatan fasilitas yang mempunyai jangkauan pelayanan terbatas pada penduduk yang ada di kota maupun di Bagian Wilayah Kota (BWK) dan Unit Lingkungan (UL).

Untuk itu kegiatan fungsional di Bagian Wilayah III dikembangkan kegiatan sebagai berikut: (a) Kegiatan primer meliputi: sentra holtikultura terutama pada sayur, apel dan bunga fasilitas agribisnis, wisata agro dan usaha jasa wisata, dan (b) Kegiatan sekunder meliputi: pasar sejenis pasar kecamatan (pasar buah), perdagangan dan jasa, fasilitas umum dan social skala BWK serta permukiman itensitas sedang.

Berdasarkan kegiatan fungsional di atas, maka Desa Punten ditetapkan sebagai desa wisata pusat pengembangan wisata agro yaitu pariwisata yang berbasis pada sektor pertanian, karena pada umumnya masyarakat desa punten mayoritas berpropesi sebagai petani apel, untuk itu Dinas Pariwisata dan Kebudayaan menetapkan dan mengembangkan desa punten dijadikan desa wisata petik apel pada tahun 2008.

Dilihat dari prespektif koordinasi, peran Dinas Pariwisata dan Pemerintah Desa Punten sudah baik dalam pemberdayaan wisata petik apel karena dalam pembuatan kebijakan untuk mengembangkan wisata petik apel pemerintah desa punten berkoordinasi dengan dinas pariwisata baik melalui Perjanjian Khusus atau MOU maupun komunikasi langsung melalui media komunikasi. Jadi, hubungan instansi yang dilakukan Dinas Pariwisata dan pemerintah desa punten adalah hubungan berkoordinasi atas kebijakan yang dibuat dari bawah ke atas dalam hal ini pemerintah desa dan masyarakat, ke dinas pariwisata. Strategi pemberdayaan yang dilakukan adalah dengan mendengar dan mengimplementasikan aspirasi masyarakat sehingga dapat memajukan pertumbuhan perekonomi masyarakat melalui sektor wisata petik apel. 
REFORMASI

ISSN 2088-7469 (Paper) ISSN 2407-6864 (Online)

Volume 8 Nomor 2 (2018)

\section{2) Motivasi}

Untuk mengembangan pariwisata, peran pemerintah dinas pariwisata untuk memotivasi sangat diperlukan agar kepariwisataan itu dapat berjalan dan usaha pariwisata terus berjalan dengan lancar. Pemerintah desa dan masyarakat merupakan sasaran utama yang perlu untuk terus diberikan motivasi agar perkembangan pariwisata dapat berjalan dengan baik. Setelah terbentuknya desa punten sebagai desa wisata petik apel Peran Dinas Pariwisata dalam memberikan motivasi agar wisata petik apel di desa punten dapat berjalan dengan baik dengan cara memberikan perintah kepada pemerintah desa punten melalui Surat Keputusan kepala dinas pariwisata dan kebudayaan kota batu, untuk membentuk kelompok sadar wisata (pokdarwis) pokdarwis dibentuk atas saran dari dinas pariwisata kepada pemerintah desa punten sehingga pemerintah desa punten membentuk kelompok sadar wisata (Pokdarwis). Bentuk saran dari dinas dengan memberikan buku panduan pembentukan kelompok sadar wisata kepada pemerintah desa punten setelah itu pemerintah desa punten mengumpulkan masyarakat untuk dibentuk kelompok sadar wisata.

Dari pernyataan diatas peneliti menyimpulkan bahwa dalam memberikan motivasi peran Dinas Pariwisata dan Pemerintah Desa sudah baik karena Dinas Pariwisata mengarahkan pemerintah desa punten untuk membentuk kelompok sadar wisata dengan memberikan buku panduan pembentukan kelompok sadar wisata tersebut. Setelah mendapat arahan dari dinas pariwisata pemerintah desa punten mengumpulkan masyarakat desa punten dan membentuk kelompok sadar wisata tersebut. Jadi, hubungan instansi yang dilakukan antar dinas pariwisata dan pemerintah desa punten merupakan hubungan berkonsultasi karena dinas pariwisata membuat keputusan agar dapat memajukan wisata petik apel. Dan strategi pemberdayaan yang dilakukan adalah dengan memberi peran kepada masyarakat agar ikut ambil andil dalam mengembangkan wisata petik apel yang ada di daerahnya sendiri.

\section{3) Fasilitas}

Dalam pengembangan obyek wisata peran Pemerintah Daerah dalam memfasilitasi segala kebutuhan kepariwisataan sehingga kepariwisataan dapat terwujud. Sebagai fasilitator pengembangan potensi pariwisata peran pemerintah adalah menyediakan segala fasilitas yang mendukung segala program yang diadakan oleh kelompok sadar wisata (Pokdarwis). Adapun pada praktiknya Dinas Pariwisata mengadakan kerja sama dengan Pemerintah Desa dalam penyediaan segala kebutuhan kelompok sadar wisata untuk menjalankan program kegiatannya.

Peran Dinas Pariwisata dan pemerintah desa dalam memfasilitasi wisata petik apel yang ada di desa Punten adalah menyediakan fasilitas yang mendukung segala program kegiatan kelompok sadar wisata. Kegiatan kelompok sadar wisata yang pernah dilakukan adalah kegiatan sosialisasi atau diskusi sadar wisata dengan masyarakat desa punten dan mengimplementasikan Sapta Pesona melalui gerakan aksi percontohan atau bakti sosial di desa. Dari program kegiatan yang dilakukan kelompok sadar wisata tersebut dinas pariwisata menyediakan instruktur pelatihan dalam kegiatan sosialisasi pengembangan wisata petik apel kepada masyarakat sedangkan pemerintah desa punten menyediakan gedung untuk kegiatan sosialisasi pengembangan wisata petik apel kepada masyarakat yaitu menggunakan gedung balai desa.

Dari pernyataan diatas peneliti menyimpulkan bahwa peran Dinas Pariwisata dan Pemerintah Desa dalam memfasilitasi wisata petik apel yaitu mendukung segala program kegiatan kelompok sadar wisata atau Pokdarwis. Dari kegiatan yang dilakukan oleh 
kelompok sadar wisata dinas pariwisata mempunyai peran sebagai penyedia instruktur pelatihan terhadap masyarakat dalam kegiatan sosialisasi pengembangan wisata petik apel sedangkan pemerintah desa menyediakan fasilitas gedung untuk kegiatan sosialisasi tersebut. Jadi hubungan antara dinas pariwisata dan pemerintah desa adalah saling mendukung satu sama lain untuk mengembangkan kelompok sadar wisata guna meningkatkan kualitas wisata petik apel. Sedangkan strategi pemberdayaan yang dilakukan adalah dengan memfasilitasi segala kebutuhan guna untuk mengembagkan sumber daya masyarakat.

\section{4) Dinamisasi}

Dalam mengembangkan kepariwisataan yang baik, perlu adanya peran yang sinergis antara dinas pariwisata, pemerintah desa dan masyarakat agar dapat mencapai suatu pembangunan yang ideal. Dinas pariwisata sebagai salah satu stakeholder pembangunan pariwisata memiliki peran untuk mensinergiskan pihak-pihak tersebut, agar diantaranya tercipta suatu simbiosis mutualisme demi perkembangan pariwisata.

Peranan dinas pariwisata adalah dengan membuat suatu branding yaitu "setiap wisatawan yang berkunjung ke batu belum lengkap jika belum menikmati wisata petik apel". Branding tersebut dibuat dalam rangka penguatan dan meningkatkan kunjungan wisatawan ke tempat wisata petik apel. Pembuatan branding tersebut di koordinasikan ke semua sektor wisata yang ada di kota batu sehingga wisata petik apel ini mudah dan cepat diketahui oleh wisatawan sehingganya dapat meningkatkan kunjungan wisatawan ke tempat wisata petik apel. Untuk mendukung branding yang dibuat oleh dinas pariwisata, pemerintah desa puten membuat posko-posko informasi untuk wisata petik apel agar wisatawan bisa lebih mudah mencari informasi berkaitan dengan wisata petik apel.

Dilihat dari prespektif dinamisator, peranan Dinas Pariwisata dan Pemerintah Desa Punten sudah baik karena dalam pengembangan wisata petik apel dinas pariwisata membuat branding untuk meningkatkan kunjungan wisatawan berkunjung ke desa wisata petik apel di desa punten dan pemerintah desa punten juga membuat memfasilitasi dengan menyediakan posko-posko informasi untuk wisata petik apel agar wisatawan bisa lebih mudah berkunjung kesana. Jadi, hubungan instansi yang dilakukan antara dinas pariwisata dan pemerintah desa punten merupakan hubungan fungsional dimana antar instansi saling mendukung program yang dibuat oleh instansi yang lebih tinggi. Sedangkan strategi yang dilakukan adalah dalam rangka penguatan dan meningkatkan kunjungan wisatawan ke tempat wisata petik apel.

\section{B. Strategi Dinas Pariwisata dan Kebudayaan serta Pemerintah Desa}

Strategi yang dilakukan Dinas Pariwisata dan Pemerintahan Desa Punten dalam memberdayakan wisata petik apel adalah dengan cara membentuk dan memberi penguatan kepada kelompok-kelompok yang berperan langsung dalam mekanisme pengembangan wisata petik apel yaitu:

1) Pokdarwis, Pokdarwis adalah kelompok sadar wisata yang dibentuk oleh pemerintah desa dengan bimbingan dinas pariwisata. Ranah strategi di Pokdarwis adalah memberikan informasi tentang kewisataan, penguatan ikon desa punten sebagai wisata petik apel, penyebarluasan informasi melalui media sosial tentang wisata petik apel, dan pembukaan lahan untuk wisata petik apel. Peran dinas pariwisata dalam memberdayakan kelompok sadar wisata adalah dengan mengembangkan sumber daya manusia (SDM) sehingga dapat meningkatkan kualitas pengelolaan wisata petik apel, 


\section{REFORMASI}

dan peran pemerintah desa adalah dengan menyediakan fasilitas yang dibutuhkan baik dalam operasional wisata petik apel maupun dalam rangka pengembangan sumber daya manusia (SDM).

2) Gapoktan, Gapoktan adalah gabungan kelompok tani yang dibentuk oleh Pemerintah Desa sebagai implikasi dari kemampuan petani mengembangkan sektor wisata petik apel. Ranah gapoktan meliputi pelatihan, penguatan modal bagi petani apel, sebagai wadah para petani untuk memecahkan masalah dan membangun pertanian desa, dan mewujudkan pertanian yang tangguh untuk pemantapan ketahanan pangan. Peran dinas pariwisata dalam pemberdayaan gabungan kelompok tani desa punten hanya sebatas memberikan etika pergaulan dalam menerima tamu atau wisatawan yang berkunjung ke wisata petik apel. Sedangkan peran pemerintah desa hanya membetuk kepengurusan dari pada kelompok sadar wisata desa punten dan namun belum ada peran untuk memberikan pelatihan khusus karena yang mengerti masalah bertanam hanyalah kami petani apel saja.

\section{KESIMPULAN}

Peranan Dinas Pariwisata dan Kebudayaan serta Pemerintah Desa Punten Kota Batu dalam mengembangkan wisata petik apel dilakukan dengan cara mendorong masyarakat dan pemerintah daerah untuk selalu berkoordinasi. Selain itu, kerjasama antara pemerintah daerah yang dalam hal ini dilakukan oleh Dinas Pariwisata dan Kebudayan serta Pemerintah desa dengan masyarakat terus ditingkatkan. Koordinasi dan kerjasama diawali dengan kegiatan musrenbang di tingkat desa. Hasil musrembang selanjutnya disampaikan dan dikoordinasikan dengan Dinas Pariwisata melalui Perjanjian Khusus atau MoU. Hal ini selaras dengan peranan Dinas Pariwisata dan Kebudayaan serta Pemerintah Desa dalam memberikan Motivasi dengan membentuk Kelompok Sadar Wisata yang bertujuan mendukung maksimalisasi wisata petik apel. Dinas Pariwisata dan Kebudayaan serta Pemerintah Desa juga memfasilitasi kebutuhan secara maksimal guna mengembangkan wisata petik apel dengan mendukung program kegiatan yang dilakukan oleh Kelompok Sadar Wisata. Selain itu, untuk meningkatkan kunjungan wisatawan, Dinas Pariwisata dan Kebudayaan serta Pemerintah Desa bekerjasama dengan semua pihak yang bergerak di sektor wisata Kota Batu untuk membuat suatu branding Wisata Petik Apel.

\section{DAFTAR PUSTAKA}

Bugin, Burhan. 2007. Penelitian Kualitatif. Jakarta: Prenada Media Grup.

Moleong, Lexy J. 2012. Metodeologi Penelitian Kualitatif. Jakarta: Alfabeta.

Mardikanto, Totok. 2013. Pemberdayaan Masyarakat dalam Prespektif Kebijakan Publik. Bandung. Alfabeta.

Pitana I Gde, Gayatri Putu G. 2005. Sosiologi Pariwisata. Yogyakarta : C.V Andi Offset Sugiyono. 2013. Metode Penelitian Pendidikan Pendekatan Kuantitatif, Kualitatif, dan $R$ \& $D$. Bandung: Alfabeta

Undang-Undang Nomor 23 Tahun 2014 Pemerintahan Daerah 